\title{
DAMPAK SUBSIDI TERHADAP SURPLUS PRODUSEN DAN TOTAL BENEFIT PERIKANAN TANGKAP PANTURA JAWA TENGAH
}

\author{
Armen Zulham ${ }^{1}$
}

\begin{abstract}
ABSTRAK
Subsidi merupakan kebijakan fiskal, melalui subsidi perikanan pemerintah berupaya meningkatkan taraf hidup nelayan. Salah satu indikator untuk menilai peningkatan taraf hidup nelayan akibat dari subsidi adalah surplus produsen dan total benefit dari eksploitasi potensi ikan. Penelitian ini menggunakan quaterly data 1998 - 2002, pada delapan lokasi pendaratan ikan di Pantura Jawa Tengah. Penelitian ini menghitung surplus produsen berdasarkan: baseline (tanpa subsidi) dan subsidi. Perhitungan surplus produsen dilakukan dengan program Maple dengan memasukkan koefisien yang diperoleh dari pendekatan regresi. Secara umum hasil analisis tersebut menunjukkan subsidi perikanan akan mendorong peningkatan surplus produsen. Pengaruh subsidi perikanan yang meningkatkan surplus produsen dalam jumlah yang relatif tinggi terjadi pada daerah Kabupaten Brebes, Kota Tegal, Kabupaten Tegal, Kabupaten Pemalang, dan Kota Pekalongan. Sementara pengaruh subsidi perikanan terhadap peningkatan surplus produsen di Kabupaten Batang, Kabupaten Pekalongan dan Kabupaten Kendal dapat dikatakan relatif kecil. Peningkatan surplus produsen belum tentu meningkatkan total benefit, hal ini terjadi jika surplus produsen baseline lebih besar dari surplus produsen subsidi. Penelitian ini merekomendasikan bahwa pemberian subsidi pada perikanan tangkap perlu lebih teliti dan terarah agar tujuan alokasi subsidi tersebut dapat lebih efektif.
\end{abstract}

Kata kunci: Subsidi Perikanan, Surplus Produsen, Total Benefit, Perikanan Tangkap.

\section{Abstract: Impact Of Subsidy On Producer Surplus And Total Benefit In The North Coast of the Central Java Fishery. By Armen Zulham.}

Subsidy is a fiscal policy; fisheries subsidy proposed by the government intended to support the the standart of living for fishing community. Producer surplus and total benefit could be used as indicators to measured the impact of subsidy on the fishery. The quaterly data from 1998 - 2000 from 8 fish landing centers in Northcoast of Central Java were used in the analysis. The producer surpluses were calculated for baseline and subsidy. The Maple software was used to calculate producer surpluses. In general fisheries subsidy lead to increase producer surplus. A relatively high impact of fisheries subsidy on producer surplus was indicated by Kabupaten Brebes, Kota Tegal, Kabupaten Tegal, Kabupaten Pemalang, and Kota Pekalongan. Meanwhile, the increasing of producer surplus in Kabupaten Batang, Kabupaten Pekalongan and Kabupaten Kendal was indicating relatively low. The increasing value of producer surplus is not necessary follow by the increasing value of the total benefit, particularly when the baseline's producer surplus is greater than subsidy's producer surplus. This research recommends that the fisheries subsidies should be allocated properly to the fishery in order to ensure the effectiveness of the policy.

Keywords: Fisheries Subsidies, Producer Surplus, Total Benefit, Capture Fishery

\section{PENDAHULUAN}

Subsidi dalam pengertian ekonomi merupakan transfer finansial dari pemerintah kepada produsen dan konsumen. Pada sektor perikanan, transfer finansial tersebut diberikan kepada nelayan atau armada penangkapan ikan melalui berbagai program yang terkait dengan pembangunan sektor tersebut.

Transfer finansial tersebut, bentuknya dapat langsung maupun tidak langsung.

\footnotetext{
${ }^{1}$ Peneliti pada Balai Besar Riset Sosial Ekonomi Kelautan dan Perikanan

JI. KS. Tubun Petamburan VI, Jakarta 10260

Telp. $02153650162 / F a x .02153650159$
} 
Transfer finansial langsung merupakan subsidi langsung yang diberikan kepada nelayan dalam bentuk paket bantuan atau pelatihan nelayan. Transfer finansial tidak langsung merupakan subsidi tidak langsung yang diperoleh nelayan sebagai akibat dari kebijakan pemerintah yang berhubungan dengan pemanfaatan sumberdaya perikanan. Bentuk subsidi tidak langsung yang dirasakan nelayan antara lain adalah ketersediaan prasarana pelabuhan perikanan.

Subsidi langsung dapat menyebabkan rendahnya biaya operasi penangkapan ikan, sedangkan subsidi tidak langsung dapat mendorong peningkatan kualitas ikan hasil tangkapan, karena semakin sempurnanya infrastruktur yang mendukung usaha perikanan. Kebijakan ini mendorong tumbuhnya surplus produsen, tetapi menjadi pemicu overcapacity dalam penangkapan ikan. Akibatnya pengaruh subsidi dari pemanfaatan potensi ikan didalam perairan menjadi tersamar (ambiguity).

Pada sidang negotiating group on rule, World Trade Organization (WTO) tanggal 5 7 Mei 2003 di Jenewa, menunjukkan setiap negara mempunyai pandangan tersendiri mengenai subsidi perikanan di negara masing-masing. Sementara itu dalam forum resmi tersebut wakil Indonesia belum memberikan keputusan kongkrit tentang kebijakan subsidi perikanan dalam sektor perikanan Indonesia (DKP, 2003), seakan didalam sektor perikanan Indonesia tidak ada kebijakan subsidi. Pada Juli 2007, Indonesia telah memberi pendapat tentang keberadaan subsidi perikanan dalam pembangunan perikanan (WTO,2007).

Jika batasan WTO serta definisi yang disusun oleh MRAG (2000) dijadikan acuan, maka kebijakan subsidi itu telah diimplementasikan pada sektor perikanan Indonesia sejak Pelita I. Batasan ini menunjukkan subsidi perikanan mencakup dua substansi, yaitu:

(1). Berbagai jenis transfer finansial yang diberikan pemerintah kepada kapal/armada penangkap ikan.

(2). Keuntungan(benefit) ekonomi yang diperoleh masyarakat nelayan karena kebijakan pemerintah terhadap sektor perikanan.

Berkaitan dengan perikanan tangkap Indonesia, maka subsidi yang dimaksudkan dalam tulisan ini adalah kontribusi finansial yang disediakan pemerintah melalui kebijakan alokasi anggaran pembangunan dalam rangka pemanfaatan potensi ikan. Anggaran pembangunan tersebut dialokasikan untuk mencapai berbagai program pembangunan. Sebagian dari anggaran pembangunan perikanan itu terkait dengan subsidi langsung dan sebagian lagi merupakan subsidi tidak langsung. Batasan tersebut sejalan dengan definisi operasional Schrank and Keithly (1999) dan Schrank (2000) yang menunjukkan subsidi adalah berbagai program pemerintah yang potensial mendorong perolehan keuntungan.

Dengan demikian yang perlu dipelajari adalah bagaimana pengaruh subsidi perikanan terhadap kesejahteraan nelayan sebagai produsen. Apakah kesejahteraan produsen semakin baik, menurun atau tidak berpengaruh dengan adanya kebijakan itu ? Oleh sebab itu tujuan tulisan ini adalah melihat bagaimana pengaruh subsidi terhadap kesejahteraan nelayan melalui surplus produsen dan total benefit (dinotasikan sebagai $\Delta$ TB) dari pemanfaatan sumberdaya perikanan tersebut.

\section{METODOLOGI}

\section{Kerangka Teoritis}

Upaya untuk mempelajari surplus produsen pada perikanan tangkap telah dirintis oleh Anderson (1980) dalam artikel Necessary Component of Economic Surplus in Fisheries Economics dengan mempelajari permintaan dan penawaran tenaga kerja dari sektor industri perikanan dan sektor industri lainnya. Sementara itu Copes (1972) mempelajari surplus ini melalui backward 
binding supply curve pada pasar bersaing sempurna dan pasar tidak bersaing sempurna, hal ini dapat dilihat pada artikel Factor Rent, Sole Ownership and the Optimum Level of Fisheries Exploitation. Kedua artikel itu belum mempelajari pengaruh dari instrumen kebijakan dalam perikanan tangkap.

Tulisan lain seperti Henderson and Quant (1985), Nicholson (1985) dan Jehle (1991) menggunakan pendekatan keseimbangan parsial untuk mempelajari dampak dari kebijakan pemerintah seperti: pajak, subsidi ataupun kebijakan lainnya untuk melihat pengaruhnya pada pendapatan masyarakat. Dengan demikian dampak dari kebijakan pemerintah tersebut dapat diukur melalui pendekatan surplus konsumen dan surplus produsen.

Secara teoritis, subsidi yang diberikan pemerintah tersebut akan memberi dampak penting terhadap nelayan, untuk melihat hal itu digunakan Gambar 1. Jika pasar komoditas tersebut diasumsikan pasar bersaing sempurna, secara sederhana surplus produsen merupakan daerah $\mathrm{P}_{2} \mathrm{P}^{*} \mathrm{~A}$, daerah diatas kurva penawaran dan dibawah garis harga P*A. Kurva penawaran merupakan biaya marginal dari setiap barang yang diproduksi, karena itu $\mathrm{P}_{2} \mathrm{P}^{*} \mathrm{~A}$ merupakan selisih antara total biaya variabel $\mathrm{OP}_{2} \mathrm{AQ}^{*}$ dengan pendapatan kotor OP*AQ* Hal ini merupakan surplus produsen yang sama artinya dengan penerimaan dikurangi dengan biaya variabel.

Surplus produsen ini dalam pandangan Marshalian secara matematika dituliskan sebagai :

$$
\mathrm{PS}=\int_{P_{2}}^{P^{*}} Q(P, \alpha) d P \text {. }
$$

Sedangkan menurut pandangan Walrasiand apat dituliskan sebagai:

$\mathrm{PS}=\mathrm{P}^{*} \mathrm{Q}^{*}-\int_{0}^{Q^{*}} f(Q) d Q$

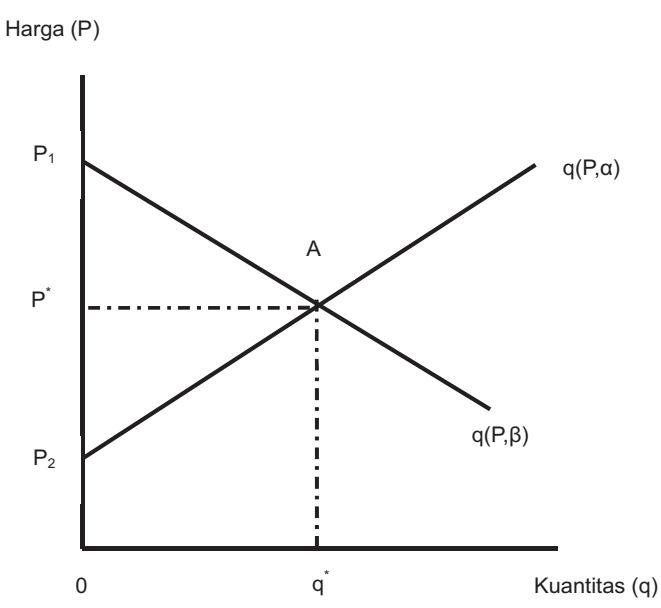

Gambar1. Surplus Produsen dalam Kegiatan Penangkapan Ikan

Figure1. Producer Surplus in Capture Fisheries

Surplus produsen sangat tergantung pada bentuk fungsional dari fungsi penawaran, sehingga perubahan kebijakan pemerintah terhadap penawaran suatu barang dalam pasar akan mempengaruhi surplus produsen. Hal inilah yang menjadi dasar dari kajian ini untuk melihat efek kesejahteraan akibat dari subsidi tersebut.

\section{Model Operasional}

Berdasarkan Gambar 1, jika P adalah harga ikan komposit pada masing-masing lokasi dan $Q$ adalah jumlah ikan yang didaratkan nelayan pada setiap lokasi. Estimasi harga melalui fungsi penawaran pada persamaan (2) tidak memperoleh hasil seperti yang diharapkan.

$$
P=\alpha_{1}+\beta_{1} Q
$$

Dimana: $\alpha_{1}$ dan $\beta_{1}>0$.

Oleh sebab itu estimasi persamaan (2) dilakukan melalui fungsi suplai perikanan (backward binding supply curve). Fungsi itu, diperoleh dari fungsi biofisik stok ikan di perairan yang diasumsikan sebagai:

$$
F(X)=a X-b X^{2}
$$


Dimana: a dan b adalah parameter biologi, $X$ adalah stok ikan, sementara fungsi penangkapan ikan yang dilakukan oleh armada tangkap adalah:

$$
h=q E X
$$

Jika diasumsikan $q=1$, dan $E$ adalah effort penangkapan ikan, maka fungsi penangkapan ikan menjadi $\mathrm{h}=\mathrm{E} \mathrm{X}$. Dalam kondisi steady state $h=F(X)$, dengan demikian tingkat keseimbangan dari stok ikan $(X)$ dan hasil tangkapan (h), masing-masing adalah:

$\mathrm{X}=\frac{a}{b}-\frac{E}{b}$

sehingga : $\mathrm{h}=\mathrm{E}\left(\frac{a}{b}-\frac{E}{b}\right)$

Jika $\frac{a}{b}=\alpha$ dan $\frac{1}{b}=\beta$, maka $\mathrm{h}=\alpha \mathrm{E}-\beta \mathrm{E}^{2}$.

Pada perikanan yang common property, keseimbangan akan terjadi apabila total pendapatan sama dengan total biaya. Selanjutnya jika $P=1$, maka total pendapatan sama dengan $\mathrm{TR}=\mathrm{h}$ dan $\mathrm{TC}=\mathrm{c}$. $\mathrm{E}$, dan $\mathrm{c}$ adalah biaya per unit effort sehingga $h=c$. $E$. Dengan demikian $\alpha E-\beta E^{2}=c$. $E$, oleh sebab itu pada perikanan yang common property keseimbangan effort penangkapan ikan (E) adalah

$$
\mathrm{E}=\frac{\alpha-c}{\beta}=\mathrm{a}-\mathrm{bc}
$$

karena $\mathrm{h}=\mathrm{c}$. E, maka $\mathrm{h}=\mathrm{c}(\mathrm{a}-\mathrm{bc})=\mathrm{ac}-\mathrm{bc} \mathrm{c}^{2}$. Jika, harga hasil tangkapan sama dengan biaya rata-rata hasil tangkapan, maka $\mathrm{P}=\frac{c . E}{h}$, selanjutnya dari persamaan $h=\alpha E-\beta E^{2}$, dapat diperoleh:

$$
E= \pm \sqrt{-\frac{h}{\beta}+\left(\frac{\alpha}{2 \beta}\right)^{2}+\frac{\alpha}{2 \beta}}
$$

kemudian $: \mathrm{AC}=\frac{2 c}{\alpha \pm \sqrt{-4 \beta \cdot h+\alpha^{2}}}$
Dengan demikian AC merupakan fungsi suplai perikanan yang tergantung pada hasil tangkapan (h). Fungsi ini merupakan backward binding supply function. Sementara itu, c merupakan biaya penangkapan per unit hasil tangkapan, sedangkan $\alpha$ dan $\beta$ adalah parameter biofisik, yang diestimasi dengan tehnik CYP (Clarke, Yoshimoto and Pooley,Clarke et al, 1992l).

Dinamika surplus produsen didekati dengan fungsi suplai perikanan (backward binding supply curve) pada persamaan (9). Dengan mengikuti Gambar 1 sehingga secara numerik surplus produsen (PS) tersebut dapat dituliskan sebagai:

$$
\mathrm{PS}=p_{o} q_{o}-\int_{0}^{q_{0}} \frac{2 c}{\alpha+\sqrt{-4 \beta+\alpha^{2}}}
$$

Integral dari bagian terakhir persamaan diatas dapat dituliskan sebagai:

$$
\begin{gathered}
\frac{1}{2} \frac{c a 1 n(q)}{\beta}-\frac{c \sqrt{-4 \beta q+a^{2}}}{\beta}+\frac{1}{2} \frac{c a \ln \left(a+\sqrt{-4 \beta q+a^{2}}\right)}{\beta} \\
-\frac{1}{2} \frac{c a \ln \left(\sqrt{\left.-4 \beta q+a^{2}-a\right)}\right.}{\beta}
\end{gathered}
$$

Sehingga surplus produsen tersebut adalah :

$$
\begin{aligned}
& P S=\text { po } q o-\frac{1}{2} \frac{c \alpha \ln (q)}{\beta}+\frac{c \sqrt{-4 \beta q+\alpha^{2}}}{\beta} \\
& -\frac{1}{2} \frac{c \alpha \ln \left(\alpha+\sqrt{-4 \beta q+\alpha^{2}}\right.}{\beta}+\frac{1}{2} \frac{c \alpha \ln \left(\alpha-\sqrt{-4 \beta q+\alpha^{2)}}\right.}{\beta}
\end{aligned}
$$

Surplus produsen dapat dihitung dengan memasukkan harga ikan per ton $(p)$, jumlah hasil tangkapan (ton), biaya per unit hasil tangkapan (c) ke dalam persamaan yang terakhir tersebut. Subsidi pada perikanan tangkap cenderung akan menurunkan biaya per unit hasil tangkapan.

\section{Jenis dan Sumber Data}

Pengambilan data primer dilaksanakan pada bulan Juli sampai Agustus tahun 1999. Data primer yang digunakan adalah data ex 
vessel bulan Agustus 1999 pada 8 lokasi pendaratan ikan di Pantai Utara (Pantura) Jawa Tengah. Data ini digunakan sebagai data dasar untuk memprediksi perkembangan biaya dan harga pada lokasi penelitian per triwulan selama periode analisis dengan memanfaatkan laju inflasi.

Data laju inflasi diperoleh dari Indeks Harga Konsumen (IHK), ikan segar Kota Tegal dengan tahun dasar 1996. Indeks Harga Konsumen dari lokasi penelitian hanya terdapat di Kota Tegal terbitan Badan Pusat Statistik. Indeks Harga Konsumen ikan segar ini dimanfaatkan, karena Indeks Harga Produsen (IHP) ikan segar tidak diperoleh untuk seluruh lokasi penelitian. Penggunaan indikator Indeks Harga Konsumen sebagai proksi dari perilaku perubahan harga pada
Kabupaten Kendal. Pembedaan lokasi pendaratan ikan ini dimaksudkan untuk melihat pengaruh subsidi terhadap surplus produsen dan total benefit pada masingmasing lokasi pendaratan ikan.

Data harga dan biaya penangkapan ikan diperoleh dari responden. Jumlah responden dari kapal penangkap ikan sebanyak 842 responden. Responden yang diwawancara adalah nahkoda atau pemilik kapal/perahu penangkap ikan. Kedua responden tersebut dianggap merupakan pihak yang paling memahami berbagai kebutuhan kapal/perahu penangkap ikan untuk operasi penangkapan ikan. Sebaran jumlah nelayan contoh menurut kapal/perahu penangkap ikan dapat dilihat pada Tabel 1.

Data sekunder terdiri dari dua kelompok:

Tabel 1. Sebaran Responden menurut lokasi Tempat Pendaratan Ikan Di Pantura Jawa Tengah

Table 1. Distribution of Responden based on Fish Landing Center in North Coast of Central Java.

\begin{tabular}{|c|c|c|c|c|}
\hline \multirow[b]{2}{*}{$\begin{array}{c}\text { Lokasi Pendaratan } \\
\text { Ikan/Fish Landing } \\
\text { Location }\end{array}$} & \multicolumn{4}{|c|}{ Jumlah Responden /Number of Respondens } \\
\hline & $\begin{array}{c}\text { Perahu Tanpa } \\
\text { Motor(PTM)/ } \\
\text { Canoe/Boat }\end{array}$ & $\begin{array}{c}\text { Motor Tempel } \\
\text { (MT)/ } \\
\text { Outboard } \\
\text { Motor Boat }\end{array}$ & $\begin{array}{c}\text { Kapal Motor } \\
(\mathrm{KM}) / \\
\text { Inboard } \\
\text { Motor Boat }\end{array}$ & $\begin{array}{c}\text { Jumlah/ } \\
\text { Total }\end{array}$ \\
\hline Kab. Brebes & - & 30 & - & 30 \\
\hline 2. Kota Tegal & - & - & 60 & 60 \\
\hline Kab. Pemalang & - & 67 & - & 67 \\
\hline Kab. Kendal & - & 180 & - & 180 \\
\hline Kab. Batang & - & 192 & - & 192 \\
\hline Kab Tegal & - & 220 & - & 220 \\
\hline Kota Pekalongan & - & - & 60 & 60 \\
\hline 8. Kab. Pekalongan & - & 33 & - & 33 \\
\hline Jumlah / Total & - & 722 & 120 & 842 \\
\hline
\end{tabular}

tingkat produsen ini dilakukan dengan justifikasi, wilayah Kota Tegal relatif terbatas, sehingga perbedaan harga tingkat konsumen dan produsen relatif tidak signifikan.

Data suplai ikan merupakan data time series dari 8 lokasi pendaratan ikan untuk periode 1998 - 2003. Lokasi pendaratan ikan tersebut meliputi: Kota Tegal, Kota Pekalongan, Kabupaten Brebes, Kabupaten Tegal, Kabupaten Batang, Kabupaten Pemalang, Kabupaten Pekalongan dan
Pertama, data yang terkait dengan profil makro perikanan tangkap disepanjang perairan Pantura Jawa. Data ini mencakup data hasil tangkapan menurut kelompok armada tangkap, serta jumlah armada tangkap. Data alokasi subsidi dalam anggaran pembangunan sektor perikanan. Data yang dikumpulkan merupakan data series 1975 2000. Data ini dikumpulkan dari Direktorat Jenderal Perikanan (sekarang Direktorat Jenderal Perikanan Tangkap). 
Kedua, data yang terkait dengan profil eksploitasi potensi ikan pada 8 lokasi di Pantura Jawa Tengah. Data itu meliputi data hasil tangkapan nelayan, data jumlah trip penangkapan ikan pada 8 lokasi pendaratan ikan. Data yang terakhir ini merupakan data bulanan dari tahun 1998 sampai tahun 2002.

Ketiga, pengolahan data untuk memperoleh koefisien biofisik dilakukan dengan program shazam, nilai parameter koefisien biofisik hasil regresi tersebut dimasukkan dalam persamaan 11 dengan menggunakan program Maple dan dilanjutkan dengan menggunakan sofware Excell.

\section{HASIL DAN PEMBAHASAN}

\section{Daya Dukung Potensi Ikan}

Daya dukung potensi ikan (carrying capacity) dari setiap lokasi penangkapan ikan dihitung berdasarkan jumlah ikan yang didaratkan pada masing-masing lokasi pendaratan ikan sesuai dengan Tabel 1. Perhitungan carrying capacity ini menggunakan model Gompertz dan diestimasi dengan pendekatan CYP (Clarke, Yoshimoto and Pooley, 1992). Hasil perhitungan carrying capacity lokasi penangkapan ikan dari armada yang mendaratkan ikan pada delapan lokasi tersebut telah dihitung oleh Zulham (2005) adalah seperti pada tampilan Tabel 2.

Tabel 2, menunjukkan daya dukung stok ikan pada lokasi armada yang mendaratkan ikan pada lokasi contoh. Lokasi penangkapan armada penangkapan ikan dengan stok ikan paling tinggi adalah lokasi dari armada tangkap yang mendaratkan ikan di Kota Pekalongan. Sedangkan lokasi penangkapan ikan dengan stok ikan paling rendah adalah lokasi dari armada tangkap yang mendaratkan ikan di Kabupaten Tegal, Kabupaten Pekalongan dan Kabupaten Kendal. Empat lokasi lainnya dapat dikatakan mempunyai stok ikan sedang. Lokasi itu merupakan lokasi penangkapan dari kapal yang mendaratkan ikan di Kabupaten Brebes, Kabupaten Batang, Kota Tegal dan Kabupaten Pemalang.

Kondisi stok ikan pada setiap lokasi tersebut akan terpengaruh oleh berbagai kebijakan yang diimplementasikan oleh pemerintah, baik kebijakan moneter maupun kebijakan fiskal. Implementasi dari kebijakan moneter seperti itu akan mempengaruhi dinamika ekonomi armada penangkapan ikan pada lokasi tersebut. Kebijakan kredit contohnya cenderung membuat kredit tersebut sulit dikembalikan oleh nelayan, jika stok ikan semakin terbatas. Sedangkan implikasi dari kebijakan subsidi akan bervariasi terhadap surplus produsen dan total benefit dari sumberdaya tersebut.

\section{Surplus Produsen dan Total Benefit}

Surplus produsen dalam penelitian ini dihitung berdasarkan Gambar 1, dengan bantuan persamaan (11). Surplus Produsen

Tabel2. Estimasi Daya Dukung Stok Ikan dari Armada Penangkapan Yang Mendaratkan Ikan di Tempat Pendaran Ikan Pantura Jawa Tengah

Table 2. Estimated Carrying Capacity of fish stock for Fishing Vessel Landed in North Coast of Central Java.

\begin{tabular}{clc}
\hline & $\begin{array}{c}\text { Tempat Pendaratan Ikan/ } \\
\text { Fish Landing Center }\end{array}$ & $\begin{array}{c}\text { Daya Dukung (ton per tahun)/ } \\
\text { Carrying capacity (ton per year) }\end{array}$ \\
\hline 1. & Kota Pekalongan & $120.840,21$ \\
2. & Kab. Brebes & $17.697,72$ \\
3. & Kab. Batang & $14.401,07$ \\
4. & Kota Tegal & $6.554,71$ \\
5. & Kab. Pemalang & $4.096,51$ \\
6. & Kab. Kendal & 466,31 \\
7. & Kab. Pekalongan & 462,52 \\
8. & Kab. Tegal & 206,36 \\
\hline
\end{tabular}


tersebut merupakan selisih antara pendapatan yang diperoleh seluruh kapal penangkap ikan dari memanfaatkan potensi ikan tersebut dengan besarnya biaya yang dikeluarkan untuk memanfaatkan potensi ikan tersebut. Total benefit dari eksploitasi potensi ikan tersebut merupakan gabungan antara rente ekonomi dengan surplus produsen yang diperoleh dari eksploitasi potensi tersebut. Rente ekonomi merupakan nilai pendapatan dari eksploitasi sumberdaya tersebut dikurangi dengan opportunity cost memanfaatkan sumberdaya tersebut. Jika perairan tersebut merupakan perairan private property, maka oportuinity costnya sangat tinggi, sebaliknya jika perairan tersebut merupakan perairan common property maka opportunity costnya adalah mendekati nol. Sedangkan $\Delta$ total benefit merupakan selisih antara nilai dari total benefit karena subsidi dan total benefit baseline. Dengan demikian $\Delta$ total benefit tersebut mengambarkan manfaat dari mengeksploitasi stok ikan tersebut karena kebijakan subsidi.

Tabel 3, merupakan gambaran surplus produsen dan total benefit dari beberapa

\section{Tabel 3. Surplus Produsen dan Total Benefit Beberapa Lokasi Penangkapan Ikan Pantai Utara Jawa Tengah 1998-2002.}

Table 3. Producer Surplus and Total Benefit various Fish Landing Centers in North Coast of Central Java 1998- 2002.

unit : billion Rp.

\begin{tabular}{|c|c|c|c|c|c|c|c|c|c|}
\hline \multirow{2}{*}{$\begin{array}{l}\text { Waktu/ } \\
\text { Period }\end{array}$} & \multicolumn{3}{|c|}{ Brebes } & \multicolumn{3}{|c|}{ Kendal } & \multicolumn{3}{|c|}{ Batang } \\
\hline & $\begin{array}{c}\text { PS } \\
\text { Baseline } \\
\end{array}$ & $\begin{array}{c}\text { PS } \\
\text { Subsidi } \\
\end{array}$ & $\begin{array}{c}\Delta \mathrm{T} . \\
\text { Benefit }\end{array}$ & $\begin{array}{c}\text { PS } \\
\text { Baseline }\end{array}$ & $\begin{array}{c}\text { PS } \\
\text { Subsidi } \\
\end{array}$ & $\begin{array}{c}\Delta \mathrm{T} . \\
\text { Benefit }\end{array}$ & $\begin{array}{c}\text { PS } \\
\text { Baseline } \\
\end{array}$ & $\begin{array}{c}\text { PS } \\
\text { Subsidi } \\
\end{array}$ & $\begin{array}{c}\Delta \mathrm{T} . \\
\text { Benefit }\end{array}$ \\
\hline t1-98 & $-3,69$ & 77,37 & 147,60 & 5,64 & 5,45 & 0,59 & 93,51 & 119,88 & 43,01 \\
\hline t2-98 & 0,21 & 59,22 & 106,70 & 4,42 & 4,59 & 0,48 & 156,69 & 166,32 & $-10,25$ \\
\hline t3-98 & 7,89 & 56,88 & 88,80 & 4,21 & 4,15 & 0,04 & 160,16 & 166,01 & $-31,51$ \\
\hline t4-98 & 2,52 & 107,90 & 199,30 & 6,51 & 7,33 & 2,08 & 183,44 & 213,54 & 67,28 \\
\hline t1-99 & 8,35 & 159,81 & 292,70 & 6,57 & 8,53 & 4,33 & 257,00 & 302,56 & 123,95 \\
\hline t2-99 & 1,38 & 46,78 & 80,30 & 3,05 & 3,32 & 0,49 & 69,13 & 83,08 & 3,19 \\
\hline t3-99 & 3,86 & 60,53 & 103,40 & 4,11 & 4,39 & 0,66 & 154,81 & 164,63 & $-9,64$ \\
\hline t4-99 & 14,73 & 198,02 & 357,80 & 10,59 & 12,36 & 4,50 & 381,18 & 429,38 & 166,36 \\
\hline $\mathrm{t} 1-00$ & 2,02 & 94,20 & 173,00 & 4,69 & 5,66 & 2,15 & 231,46 & 249,03 & 41,10 \\
\hline $\mathrm{t} 2-00$ & 14,77 & 128,45 & 219,50 & 7,81 & 8,63 & 2,28 & 415,05 & 418,49 & 91,14 \\
\hline t3-00 & 13,01 & 83,55 & 132,90 & 4,14 & 3,92 & 1,00 & 262,18 & 264,85 & $-3,67$ \\
\hline t4-00 & 3,39 & 64,86 & 112,80 & 0,82 & 2,05 & 2,31 & 207,38 & 211,42 & $-25,44$ \\
\hline $\mathrm{t} 1-01$ & 6,68 & 56,29 & 89,90 & 3,14 & 3,57 & 0,84 & 183,02 & 181,78 & $-78,43$ \\
\hline $\mathrm{t} 2-01$ & 7,05 & 79,02 & 134,60 & 4,44 & 5,07 & 1,41 & 247,68 & 252,66 & $-1,74$ \\
\hline t3-01 & 3,44 & 54,60 & 92,30 & 4,17 & 4,10 & 0,01 & 156,84 & 163,19 & $-29,13$ \\
\hline $\mathrm{t} 4-01$ & 3,52 & 72,91 & 128,50 & 4,31 & 4,86 & 1,25 & 222,98 & 229,60 & $-5,11$ \\
\hline $\mathrm{t} 1-02$ & 7,49 & 63,02 & 101,90 & 3,08 & 3,67 & 1,19 & 203,04 & 204,68 & $-42,87$ \\
\hline t2-02 & 7,17 & 75,05 & 126,50 & 2,18 & 3,27 & 2,14 & 174,13 & 188,13 & 13,30 \\
\hline t3-02 & 13,92 & 112,54 & 189,20 & 7,37 & 7,91 & 1,69 & 327,89 & 338,42 & 54,67 \\
\hline t4-02 & 24,78 & 227,21 & 398,70 & 9,84 & 9,36 & 7,41 & 743,07 & 739,15 & 365,58 \\
\hline
\end{tabular}

Keterangan/Remarks :PS = Surplus Produsen/Producer Surplus 
pusat pendaratan ikan di Pantura Jawa Tengah dengan stok ikan seperti pada Tabel 2. Brebes merupakan tempat pendaratan ikan dari armada penangkap ikan dari lokasi yang carrying capacity stok ikan $\mathrm{K}=17.697,72$ ton/tahun, Kendal merupakan tempat pendaratan ikan dari armada penangkap ikan dari lokasi stok ikan dengan carrying capacity $\mathrm{K}=466,31$ ton/tahun, Batang merupakan tempat pendaratan ikan dari dari armada penangkap ikan dari lokasi stok ikan dengan carrying capacity $\mathrm{K}=14.401,07$ ton/tahun.

PS Baseline pada Tabel 3, menunjukkan gambaran surplus produsen tanpa subsidi. Tabel tersebut juga memberikan gambaran tentang pengaruh kebijakan subsidi terhadap produsen dan nilai sumberdaya ikan. Secara umum kebijakan subsidi pada armada penangkapan ikan tidak selamanya akan meningkatkan surplus produsen dan total benefit.

Pada armada yang mendaratkan ikan di Brebes subsidi tersebut dapat meningkatkan surplus produsen dan total benefit. Hal ini berarti kebijakan subsidi pada armada penangkapan didaerah tersebut mempunyai implikasi positif terhadap armada tangkap dari daerah tersebut. Nilai manfaat dari sumberdaya pada lokasi penangkapan nelayan Brebes dapat dikembangkan lagi dengan memanfaatkan kebijakan subsidi.

Pada sisi lain, kebijakan subsdi pada armada tangkap di Kabupaten Kendal tidak berpengaruh signifikan terhadap peningkatan surplus produsen. Kebijakan subsidi pada armada tangkap di Kendal ini berpotensi mendorong stok ikan pada lokasi penangkapan tersebut semakin berkurang. Hal ini berarti jika subsidi tersebut diperbesar maka pada sumberdaya ikan tersebut cenderung terjadi lebih tangkap. Dan peluang keberhasilan program yang terkait dengan kebijakan moneter sangat rendah.

Sementara itu pemberian subsidi terhadap armada penangkapan ikan di Kab. Batang tidak menunjukkan peningkatan surplus produsen. Kebijakan subsidi terhadap armada tangkap tersebut tidak menunjukkan peningkatan surplus produsen yang cukup signifikan, dan cenderung menurunkan total nilai manfaat/benefit dari stok ikan dari fishingground nelayan tersebut. Informasi ini menunjukkan juga kebijakan subsidi pada armada dari daerah ini cenderung mendorong armada tangkap dari daerah itu melakukan tangkap lebih dari stok yang ada.

Tabel 4 mengambarkan lokasi penangkapan armada tangkap yang menangkap ikan pada lokasi dengan stok ikan tinggi (armada yang mendaratkan ikan di Kota Pekalongan) dan lokasi dengan stok ikan rendah (armada yang mendaratkan ikan di Kabupaten Tegal).

Kebijakan subsidi terhadap armada penangkapan Kota Pekalongan cenderung meningkatkan surplus produsen. Sementara itu total benefit dari sumberdaya perikanan tersebut cenderung fluktuatif dan ada indikasi bahwa armada tangkap dari kota Pekalongan ini cendrung lebih tangkap. Oleh sebab itu pemberian subsidi terhadap nelayan dari Kota Pekalongan ini perlu dilakukan dengan cermat agar stok ikan pada lokasi penangkapan dari armada tangkap kapal asal Kota Pekalongan tidak over fishing.

Sementara itu surplus produsen dari armada tangkap Kabupaten Tegal menunjukkan fenomena bahwa kebijakan subsidi tersebut mendorong peningkatan surplus produsen, namun kebijakan tersebut cenderung mengurangi nilai total benefit dari sumberdaya ikan pada fishing ground tersebut. Hal ini berarti jika armada tangkap dari Kabupaten Tegal tersebut diberi subsidi terus menerus oleh pemerintah maka stok ikan pada lokasi penangkapan dari armada tersebut berpotensi akan terkuras jika besaran subsidi diperbesar oleh pemerintah.

Tabel 5 memberi gambaran pengaruh kebijakan subsidi terhadap surplus produsen dan kondisi nilai sumberdaya ikan dari armada penangkapan ikan di Kab. Pemalang, Kab. Pekalongan dan Kota Tegal. Kebijakan subsidi terhadap armada tangkap di Kabupaten 
Tabel 4. Surplus Produsen dan Total Benefit dari Armada yang Penangkapan Di Kota Pekalongan dan Kabupaten Tegal1998 - 2002.

Table 4. Producer Surplus and Total Benefit For Fish Landing Center in Pekalongan City and Tegal District, 1998 - 2002.

unit : billion Rp.

\begin{tabular}{|c|c|c|c|c|c|c|}
\hline \multirow{2}{*}{$\begin{array}{l}\text { Waktu } \\
\text { Period }\end{array}$} & \multicolumn{3}{|c|}{ Kota Pekalongan } & \multicolumn{3}{|c|}{ Kabupaten Tegal } \\
\hline & PS Baseline & PS Subsidi & $\begin{array}{c}\text { Total } \\
\text { Benefit }\end{array}$ & $\begin{array}{c}\text { PS } \\
\text { Baseline }\end{array}$ & $\begin{array}{c}\text { PS } \\
\text { Subsidi }\end{array}$ & $\begin{array}{c}\text { Total } \\
\text { Benefit }\end{array}$ \\
\hline $\mathrm{t} 1-98$ & 562,86 & 757,09 & 314,27 & 2,31 & 4,61 & 4,43 \\
\hline t2-98 & 268,41 & 456,54 & 243,00 & 2,49 & 3,97 & 4,06 \\
\hline t3-98 & 460,38 & 571,96 & 49,46 & 0,27 & 2,34 & 4,83 \\
\hline t4-98 & 460,16 & 460,16 & 305,22 & 1,68 & 5,39 & 5,63 \\
\hline $\mathrm{t} 1-99$ & 931,43 & 1373,93 & 1019,15 & 3,77 & 8,74 & 5,42 \\
\hline t2-99 & 316,40 & 436,19 & 56,77 & 1,56 & 2,85 & 4,29 \\
\hline t3-99 & 551,21 & 662,84 & 72,53 & 2,74 & 4,13 & 3,95 \\
\hline t4-99 & $1.808,75$ & $2.168,11$ & 1259,94 & 8,40 & 13,18 & 2,25 \\
\hline $\mathrm{t} 1-00$ & 609,90 & 859,81 & 468,09 & 3,22 & 5,83 & 4,16 \\
\hline $\mathrm{t} 2-00$ & 155,83 & 643,81 & 879,80 & 6,86 & 9,34 & 1,96 \\
\hline $\mathrm{t} 3-00$ & 94,26 & 480,34 & 562,70 & 6,02 & 6,94 & 2,10 \\
\hline t4-00 & 155,58 & 390,94 & 346,87 & 3,61 & 4,87 & 3,56 \\
\hline $\mathrm{t} 1-01$ & 272,08 & 434,16 & 175,96 & 4,01 & 4,69 & 3,42 \\
\hline $\mathrm{t} 2-01$ & 302,64 & 555,46 & 403,13 & 2,91 & 4,93 & 4,04 \\
\hline $\mathrm{t} 3-01$ & 310,61 & 462,40 & 150,61 & 2,68 & 3,86 & 3,98 \\
\hline $\mathrm{t} 4-01$ & 468,18 & 659,11 & 281,67 & 4,20 & 5,58 & 3,25 \\
\hline $\mathrm{t} 1-02$ & 393,26 & 551,76 & 179,42 & 2,39 & 3,93 & 4,11 \\
\hline t2-02 & 332,74 & 560,43 & 348,36 & 2,21 & 4,30 & 4,37 \\
\hline $\mathrm{t} 3-02$ & 806,97 & 1060,86 & 544,87 & 5,95 & 8,12 & 2,41 \\
\hline $\mathrm{t} 4-02$ & 580,46 & 1370,36 & 1625,76 & 13,64 & 17,53 & $-2,06$ \\
\hline
\end{tabular}

Keterangan/Remarks :PS = Surplus Produsen/Producer Surplus

Pekalongan tidak mendorong peningkatan surplus produsen. Oleh sebab itu dampak kebijakan subsidi terhadap armada tangkap dari daerah ini kurang baik, Alokasi subsidi yang berlebihan terhadap armada di daerah Kabupaten Pekalongan cenderung mendorong pengurangan stok ikan. Pemberian kredit terhadap armada tangkap dari daerah ini berpotensi menghadapi kredit macet, karena nilai dari sumberdaya cenderung rendah.

Pada lokasi di Kabupaten Pemalang dan
Kota Tegal pengaruh kebijakan subsidi terhadap surplus produsen kurang menunjukkan peningkatan yang signifikan. Artinya pengaruh kebijakan subsidi pada armada tangkap pada daerah ini sangat kecil terhadap peningkatan surplus produsen. Kebijakan subsidi pada armada tangkap dari Kab. Pemalang dan Kota Tegal tersebut cenderung menurunkan total benefit. Dengan demikian jika kebijakan subsidi tetap dipertahankan maka program-program yang terkait dengan kebijakan moneter pada 
Tabel 5.Surplus Produsen dan Total Benefit dari Armada yang Penangkapan Di Kab. Pemalang, Kabupaten Pekalongan dan Kota Tegal ,1998 - 2002.

Table 5. Producer Surplus and Total Benefit For Fish Landing Center in Pemalang District, Pekalongan District and Tegal City, 1998 - 2002.

unit : billion Rp.

\begin{tabular}{|c|c|c|c|c|c|c|c|c|c|}
\hline \multirow{2}{*}{$\begin{array}{l}\text { Waktu/ } \\
\text { Period }\end{array}$} & \multicolumn{3}{|c|}{ Kabupaten Pemalang } & \multicolumn{3}{|c|}{ Kab. Pekalonagn } & \multicolumn{3}{|c|}{ Kota Tegal } \\
\hline & $\begin{array}{c}\text { PS } \\
\text { Baseline }\end{array}$ & $\begin{array}{c}\text { PS } \\
\text { Subsidi }\end{array}$ & $\underset{\text { Benefit }}{\Delta \mathrm{T} .}$ & $\begin{array}{c}\text { PS } \\
\text { Baseline }\end{array}$ & $\begin{array}{c}\text { PS } \\
\text { Subsidi }\end{array}$ & $\underset{\text { Benefit }}{\Delta \mathrm{T}}$ & $\begin{array}{c}\text { PS } \\
\text { Baseline }\end{array}$ & $\begin{array}{c}\text { PS } \\
\text { Subsidi }\end{array}$ & $\underset{\text { Benefit }}{\Delta \mathrm{T} .}$ \\
\hline $\mathrm{t} 1-98$ & 60,32 & 77,99 & 36,65 & 33,74 & 34,06 & 2,83 & 133,14 & 178,50 & 95,75 \\
\hline t2-98 & 40,78 & 55,26 & 28,66 & 28,08 & 28,22 & 0,64 & 149,17 & 155,07 & 19,09 \\
\hline t3-98 & 38,65 & 51,28 & 24,63 & 25,56 & 25,67 & $-0,19$ & 139,73 & 135,93 & $-1,36$ \\
\hline t4-98 & 98,22 & 118,88 & 46,14 & 21,06 & 22,23 & 3,80 & 137,50 & 220,37 & 174,36 \\
\hline $\mathrm{t} 1-99$ & 141,47 & 172,26 & 70,90 & 38,85 & 40,39 & 7,19 & 295,60 & 372,73 & 209,06 \\
\hline t2-99 & 37,88 & 47,87 & 18,92 & 8,44 & 8,89 & 0,53 & 107,97 & 119,21 & 13,87 \\
\hline t3-99 & 55,89 & 66,86 & 22,23 & 11,38 & 11,98 & 1,18 & 126,96 & 147,71 & 41,54 \\
\hline t4-99 & 155,51 & 197,44 & 94,49 & 37,08 & 39,29 & 8,38 & 359,38 & 455,51 & 266,74 \\
\hline $\mathrm{t} 1-00$ & 77,84 & 97,75 & 42,70 & 7,33 & 8,71 & 2,89 & 148,49 & 208,04 & 129,23 \\
\hline $\mathrm{t} 2-00$ & 115,48 & 138,17 & 52,02 & 51,39 & 51,97 & 7,48 & 279,42 & 312,24 & 121,55 \\
\hline $\mathrm{t} 3-00$ & 77,48 & 90,91 & 29,32 & 17,43 & 18,19 & 2,21 & 149,77 & 186,19 & 81,74 \\
\hline $\mathrm{t} 4-00$ & 74,08 & 82,36 & 18,20 & 15,08 & 15,66 & 1,37 & 124,15 & 153,30 & 58,89 \\
\hline $\mathrm{t} 1-01$ & 44,39 & 55,70 & 22,20 & 11,47 & 11,97 & 0,81 & 110,31 & 131,52 & 37,49 \\
\hline $\mathrm{t} 2-01$ & 67,52 & 82,68 & 32,07 & 15,30 & 16,09 & 2,11 & 157,77 & 187,78 & 70,98 \\
\hline $\mathrm{t} 3-01$ & 68,11 & 83,13 & 25,20 & 16,71 & 17,09 & 0,50 & 111,90 & 132,10 & 35,70 \\
\hline $\mathrm{t} 4-01$ & 93,11 & 99,58 & 16,79 & 12,06 & 12,85 & 1,87 & 165,61 & 183,85 & 49,90 \\
\hline $\mathrm{t} 1-02$ & 84,97 & 93,84 & 17,48 & 10,25 & 10,88 & 1,26 & 137,67 & 153,18 & 33,90 \\
\hline $\mathrm{t} 2-02$ & 71,60 & 84,12 & 26,91 & 12,26 & 13,05 & 1,89 & 131,54 & 169,15 & 79,01 \\
\hline$t 3-02$ & 102,70 & 122,00 & 43,85 & 23,96 & 25,03 & 3,90 & 194,33 & 273,75 & 150,25 \\
\hline t4-02 & 206,60 & 246,50 & 96,12 & 99,32 & 100,10 & 20,44 & 566,27 & 547,84 & 232,03 \\
\hline
\end{tabular}

Keterangan/Remarks :PS = Surplus Produsen/Producer Surplus

perikanan tangkap tersebut peluang keberhasilannya sangat kecil.

Secara ringkas pengaruh subsidi terhadap produsen dan nilai manfaat dari sumberdaya ikan tersebut dapat diperhatikan pada Tabel 6.

\section{KESIMPULAN DAN IMPLIKASI KEBIJAKAN}

Sebagai kebijakan fiskal, subsidi merupakan instrumen penting dalam mencapai tujuan pembangunan. Namun, pemberian subsidi tersebut memerlukan pertimbangan dan penelaahan yang lebih baik, karena kebijkan subsidi tersebut mempengaruhi tingkat keberhasilan program lain pada perikanan tangkap, apalagi keberhasilan sektor ini ditentukan oleh carrying capacity stock ikan pada lokasi penangkapan ikan dan dinamika dari stok ikannya.

Kajian ini menunjukkan pemberian subsidi pada nelayan perikanan tangkap pada 
Tabel 6. Pengaruh Subsidi Terhadap Surplus Produsen dan Benefit dari Sumberdaya dari Delapan Lokasi Pendaratan Ikan Di Pantura Jawa Tengah.

Table 6. The Impact of Subsidy on Producer Surplus and Resource Benefit of Eight Fish Landing Center in North Coast of Central Java.

\begin{tabular}{|c|c|c|c|}
\hline $\begin{array}{l}\text { Lokasi Pendaratan } \\
\text { Ikan/ } \\
\text { Fish Landing } \\
\text { Locations }\end{array}$ & $\begin{array}{l}\text { Surplus Produsen/ } \\
\text { Producer Surplus }\end{array}$ & $\begin{array}{l}\text { Total Manfaat/ } \\
\text { Total Benefit }\end{array}$ & $\begin{array}{c}\text { Tingkat } \\
\text { Keberhasilan } \\
\text { Program Moneter/ } \\
\text { Successful rate of } \\
\text { Monetary Program }\end{array}$ \\
\hline Kota Pekalongan & $\begin{array}{l}\text { Cenderung } \\
\text { meningkat/Tend to } \\
\text { increase }\end{array}$ & $\begin{array}{l}\text { Cenderung } \\
\text { meningkat/Tend to } \\
\text { increase }\end{array}$ & Tinggi/High \\
\hline Kab. Brebes & Meningkat/increase & Meningkat/ increase & $\begin{array}{l}\text { Sangat Tinggi/Very } \\
\text { high }\end{array}$ \\
\hline Kab. Batang & $\begin{array}{l}\text { Tidak } \\
\text { Berpengaruh/Not } \\
\text { Influenced }\end{array}$ & Menurun/Decreased & $\begin{array}{l}\text { Sangat } \\
\text { Rendah/Very low }\end{array}$ \\
\hline Kota Tegal & $\begin{array}{l}\text { Kurang } \\
\text { Berpengaruh/Less } \\
\text { influence }\end{array}$ & $\begin{array}{l}\text { Cenderung } \\
\text { Menurun/Tend to } \\
\text { Decrease }\end{array}$ & $\begin{array}{l}\text { Sangat } \\
\text { Rendah/Very low }\end{array}$ \\
\hline Kab. Pemalang & $\begin{array}{l}\text { Kurang } \\
\text { Berpengaruh/Less } \\
\text { influence }\end{array}$ & $\begin{array}{l}\text { Cenderung } \\
\text { Menurun/Tend to } \\
\text { Decrease }\end{array}$ & $\begin{array}{l}\text { Sangat } \\
\text { Rendah/Very low }\end{array}$ \\
\hline Kab. Kendal & $\begin{array}{l}\text { Tidak } \\
\text { Berpengaruh/Not } \\
\text { Influenced }\end{array}$ & Menurun/Decreased & $\begin{array}{l}\text { Sangat } \\
\text { Rendah/Very low }\end{array}$ \\
\hline Kab. Pekalongan & $\begin{array}{l}\text { Tidak } \\
\text { Berpengaruh/Not } \\
\text { Influenced }\end{array}$ & Menurun/Decreased & $\begin{array}{l}\text { Sangat } \\
\text { Rendah/Very low }\end{array}$ \\
\hline Kab. Tegal & $\begin{array}{l}\text { Kurang } \\
\text { Berpengaruh/Less } \\
\text { influence }\end{array}$ & $\begin{array}{l}\text { Cenderung } \\
\text { Menurun/Tend to } \\
\text { Decrease }\end{array}$ & $\begin{array}{l}\text { Sangat } \\
\text { Rendah/Very low }\end{array}$ \\
\hline
\end{tabular}

beberapa lokasi dapat meningkatkan surplus produsen (Kab. Brebes dan Kota Pekalongan), sehingga dampaknya masih dapat meningkatkan nilai manfaat dari sumberdaya. Pada armada tangkap ini peluang keberhasilan program pembangunan perikanan tangkap berpotensi untuk berhasil.

Pada sisi lain kebijakan subsidi terhadap perikanan tangkap pada enam lokasi pendaratan ikan pantura Jawa Tengah lainnya menunjukkan kebijakan itu tidak berpengaruh terhadap surplus produsen. Subsidi tersebut tidak mempunyai pengaruh apapun terhadap armada tangkap di Kota Tegal, Kabupaten

Tegal, Kabupaten Pemalang, Kabupaten Batang, Kabupaten Pekalongan dan Kabupaten Kendal. Dampak dari kebijakan subsidi tersebut dapat dikatakan tidak meningkatkan total benefit dari potensi ikan pada fishing ground armada tangkap tersebut. Oleh sebab itu peluang keberhasilan program pembangunan yang terkait dengan perikanan tangkap dari daerah tersebut sangat kecil.

Armada penangkapan ikan yang menangkap ikan pada wilayah dengan carrying capacity potensi stok ikan yang tinggi, subsidi perikanan cenderung meningkatkan total benefit dan surplus produsen. Pada sisi 
lain, armada tangkap yang beroperasi pada daerah dengan carrying capacity potensi ikan sedang dan rendah, kebijakan subsidi perikanan cenderung menurunkan surplus produsen dan total benefit dari pemanfaatan sumberdaya perikanan itu.

Hasil penelitian ini merekomendasikan alokasi subsidi kepada nelayan harus diberikan lebih teliti dan terarah. Jika subsidi perikanan tersebut diarahkan pada armada penangkapan ikan yang beroperasi pada wilayah dengan potensi ikan sedang dan rendah maka kebijakan tersebut harus dapat mendorong armada tersebut beroperasi keluar dari fishing ground penangkapan yang sekarang. Sementara pada fishing ground dengan potensi ikan yang melimpah subsidi tersebut digunakan sebagai instrumen untuk meningkatkat kapasitas tangkap.

\section{DAFTAR PUSTAKA}

Anderson, L.G.1980. Necessary Components of Economic Surplus in Fisheries Economics. Can. J. Fish Aqua. Sci. Vol. 37.

Copes, P. 1972. Factor Rent, Sole Ownership and the Optimum Level of Fisheries Exploitation. Manschester School of Econ. And Soc. Studies. Vol: 40.

Clarke, R.P, S.S. Yoshimoto, and S.G. Pooley. 1992. ABioeconomic Analysis of the Northern Hawaiian Islands Lobster Fishery. Mar. Res. Econ, Vol. 7.
DKP, 2003. Laporan Pembahasan Fisheries Subsidies pada Sidang Negotiating Group on Rule - WTO, 5 -7 Mei 2003. Mimeo.

Henderson, J.M and R.E Quant. 1985. Microeconomic Theory a Mathematical Approach. McGraw-Hill. Singapore.

Jehle, G.A. 1991., Advanced Microeconomic Theory. Vassar College. Prentice Hall Int. Inc. New Jersey.

MRAG. 2000. Summary Review of the Impacts of Fisheries Subsidies on Developing Countries. DfID Policy Research Programme Project.

Nicholson, W. 1985. Microeconomic Theory, Basic Principle and Extention, $3^{\text {rd }}$ Edition. Amherst College.

Schrank W.E. 2000. Subsidies for Fisheries: a Review of Concept. Paper presented at the Expert Consultation on Economic Incentives and Responsible Fisheries. FAO Fisheries Report No. 638. Rome.

Schrank W.E. and Keithly Jr. W.B. 1999. The Concept of Subsidies. Mar. Res. Econ. Vol. 14.

WTO $^{\mathrm{e}}$. 2003. Subsidies in Fisheries Sector: Possible Catagorizations. Negotiating Group on Rule (TN/RL/W/58) 10 Feb. 2003.

WTO, 2007. Fisheries Subsidies: Proposed New Disciplines. Revised Proposal from The Republic of Indonesia.

Zulham, A. 2005. Implikasi Kebijakan Subsidi Perikanan pada Pengembangan Perikanan Tangkap. (Disertasi Unpublish). Sekolah Pasca Sarjana IPB. 